TABLE 1. MES counts detected in 11 patients during cardiopulmonary bypass

\begin{tabular}{|c|c|c|c|c|c|c|c|c|}
\hline \multirow[b]{2}{*}{ Case } & \multirow[b]{2}{*}{$\begin{array}{c}\text { Age } \\
\text { (y) }\end{array}$} & \multirow[b]{2}{*}{ Sex } & \multirow[b]{2}{*}{ Bypass time (min) } & \multicolumn{5}{|c|}{ MES counts } \\
\hline & & & & Before filter & After filter & $\begin{array}{l}\text { Right } \\
\text { MCA }\end{array}$ & $\begin{array}{l}\text { Left } \\
\text { MCA }\end{array}$ & $\begin{array}{l}\text { Both } \\
\text { MCAs }\end{array}$ \\
\hline 1 & 69 & $\mathrm{~F}$ & 70 & 9258 & 6768 & 8 & 6 & 14 \\
\hline 2 & 44 & $\mathrm{M}$ & 67 & 5458 & 3469 & 97 & 148 & 245 \\
\hline 3 & 15 & $M$ & 65 & 6569 & 4610 & 462 & 389 & 851 \\
\hline 4 & 56 & $\mathrm{M}$ & 72 & 7933 & 4643 & 530 & 157 & 687 \\
\hline 5 & 70 & $\mathrm{~F}$ & 60 & 17,564 & 8091 & 160 & 126 & 286 \\
\hline 6 & 73 & $M$ & 75 & 4395 & 2363 & 23 & 29 & 52 \\
\hline 7 & 60 & $\mathrm{M}$ & 68 & 1683 & 1323 & 12 & 24 & 36 \\
\hline 8 & 66 & $M$ & 79 & 5315 & 1868 & 73 & 54 & 127 \\
\hline 9 & 49 & $\mathrm{~F}$ & 64 & 8088 & 2678 & 28 & 52 & 80 \\
\hline 10 & 78 & $\mathrm{M}$ & 55 & 26,230 & 18,458 & 31 & 15 & 46 \\
\hline 11 & 72 & $\mathrm{~F}$ & 110 & 7901 & 4861 & 102 & 98 & 200 \\
\hline \multicolumn{9}{|l|}{ Total } \\
\hline Sum & & & & 100,394 & 59,132 & 1526 & 1098 & 2624 \\
\hline Median & & & & 7343 & 4588 & 85 & 81 & 163 \\
\hline $95 \%$ Confidence interval & & & & $4927-15,132$ & $2668-9890$ & $26-279$ & 29-197 & $52-452$ \\
\hline
\end{tabular}

refrained from further evaluating MESs detected during other operation stages. Our study thus can provide no information on the relation between MES counts and various stages of cardiac surgery or surgical manipulations, because the MESs detected in this study were not caused by surgical interventions but solely by the oxygenator.

\section{References}

1. Barbut D, Lo YW, Gold JP, Trifiletti RR, Yao FS, Hager DN, et al. Impact of embolization during coronary artery bypass grafting on outcome and length of stay. Ann Thorac Surg. 1997;63:998-1002.

2. Harrison MJ, Pugsley W, Newman S, Paschalis C, Klinger L, Treasure
$\mathrm{T}$, et al. Detection of middle cerebral emboli during coronary artery bypass surgery using transcranial Doppler sonography [letter]. Stroke. 1990;21:1512.

3. Sylivris S, Levi C, Matalanis G, Rosalion A, Buxton BF, Mitchell A, et al. Pattern and significance of cerebral microemboli during coronary artery bypass grafting. Ann Thorac Surg. 1998;66:1674-8.

4. Georgiadis D, Wenzel A, Lindner A, Zerkowski HR, Zierz S. Influence of transducer frequency on Doppler microemboli signals in an in vivo model. Neurol Res. 1998;20:198-200.

5. Barbut D, Yao FS, Hager DN, Kavanaugh P, Trifiletti RR, Gold JP. Comparison of transcranial Doppler ultrasonography and transesophageal echocardiography to monitor emboli during coronary artery bypass surgery. Stroke. 1996;27:87-90.

\title{
Should HIV-positive recipients undergo heart transplantation?
}

Gianluigi Bisleri, MD, Jeffrey A. Morgan, MD, Mario C. Deng, MD, Donna M. Mancini, MD, and Mehmet C. Oz, MD, New York, NY

From the Department of Surgery, Division of Cardiothoracic Surgery, College of Physicians and Surgeons, Columbia University, New York, NY.

Received for publication June 21, 2003; accepted for publication July 14, 2003.

Address for reprints: Jeffrey A. Morgan, MD, Columbia University, College of Physicians and Surgeons, 177 Fort Washington Ave, Milstein Hospital 7GN-435, New York, NY 10032 (E-mail: jm2240@columbia. edu).

J Thorac Cardiovasc Surg 2003;126:1639-40

Copyright $\odot 2003$ by The American Association for Thoracic Surgery $0022-5223 / 2003 \$ 30.00+0$

doi:10.1016/S0022-5223(03)01216-9 everal centers have reported successful midterm results in HIV-positive patients who have undergone solid-organ transplantation. ${ }^{1,2}$ These reports have generally been limited to hepatic and renal transplantation. However, Calabrese and colleagues ${ }^{3}$ recently described a case of an HIVpositive patient who underwent successful orthotopic cardiac transplantation with midterm follow-up. The aim of this report is to describe another case of successful cardiac transplantation in an HIV-positive patient.

\section{Clinical Summary}

Our patient was a 42-year-old man with a 4-year history of HIV without any previous opportunistic infections. The patient had idiopathic cardiomyopathy with an ejection fraction of $10 \%$ and a history of multiple admissions for New York Heart Association 
TABLE 1. Review of literature on solid-organ transplantation in HIV+ recipients

\begin{tabular}{|c|c|c|c|c|}
\hline Reference & Transplants & Oraan & $\begin{array}{c}\text { Alive at } \\
\text { follow-up }\end{array}$ & $\begin{array}{c}\text { Mean } \\
\text { follow-up }\end{array}$ \\
\hline \multirow[t]{3}{*}{ Tzakis and associates 5} & \multirow[t]{3}{*}{11} & 7 livers & 28 & 1.8 \\
\hline & & 3 kidneys & 100 & 3.8 \\
\hline & & 1 heart & 100 & 2.1 \\
\hline Ragni and colleagues ${ }^{6}$ & 1 & Liver & 100 & 0.5 \\
\hline \multirow[t]{2}{*}{ Roland and Stock ${ }^{1}$} & 45 & 26 kidneys & 92 & 0.8 \\
\hline & & 19 livers & 79 & 0.8 \\
\hline
\end{tabular}

class IV heart failure, which were treated with intravenous milrinone. During this time period, his viral load was undetectable, and his absolute CD4 count was $40 \%$ to $100 \%$ of normal values (596-1140/ $\mu \mathrm{L})$.

The patient underwent an unremarkable orthotopic heart transplantation and was discharged on postoperative day 9. It is now 2 years after his transplantation, and he has since not developed any opportunistic infections, has returned to work, and is maintained on lamivudine (Epivir), viread (Tenofovir), and viramune (Nevirapine) in addition to low-dose standard immunosuppressants.

Over the 2-year follow-up period, the patient had one episode of focal acute rejection (International Society for Heart and Lung Transplantation grade 2). Serial HIV-1 blood quantification continues to demonstrate an undetectable viral load (ie, $<50$ copies of HIV-1 RNA per milliliter of plasma). The patient's CD4 cell count has remained at 650 to $1000 / \mu \mathrm{L}$.

\section{Discussion}

Since the introduction of more effective treatment options for HIV, such as protease inhibitors and antiretroviral therapy, the life expectancy of patients with HIV has significantly improved. ${ }^{4-6}$ As a consequence, an increasing number of HIV-positive patients are presenting with manifestations of end-stage organ dysfunction, such as cardiomyopathy. ${ }^{4}$ To date, there have been several reports of successful liver and kidney transplantation in HIV-positive patients (Table 1). ${ }^{1,2,5,6}$ More recently, a case report described successful heart transplantation in a patient with a 10-year history of HIV, multiple previous opportunistic infections, and Kaposi sarcoma. $^{3}$

The patient in our report had a very different preoperative clinical profile. Our patient had an undetectable viral load, normal CD4 count, and no history of opportunistic infections. This is consistent with the patient profiles that have been described in previous reports of successful liver and kidney transplantation in HIV-positive patients. ${ }^{1,2}$ It is our opinion that the presence of HIV disease in and of itself should not serve as a contraindication for heart transplantation. Cardiac transplantation might be a therapeutic option in carefully selected patients with HIV. A careful preoperative evaluation of each HIV-positive patient is warranted. We are not advocating indiscriminate transplantation of patients with HIV. Given the limited experience with transplantation in these patients, we believe that cardiac transplantation should be reserved for only those HIV-positive patients with undetectable viral loads, normal CD4 counts, and no history of opportunistic infections. In this subset of patients, it is possible that survival might be similar to that of patients without HIV. It is important for single centers to report their transplant experience in HIV-positive patients. However, study of more patients with longer follow-up periods is necessary before definitive statements regarding their outcome and allocation of scarce resources can be made.

\section{References}

1. Roland ME, Stock PG. Review of solid-organ transplantation in HIVinfected patients. Transplantation. 2003;75(4):425-9.

2. Halpern SD, Ubel PA, Caplan AL. Solid-organ transplantation in HIVinfected patients. $N$ Engl J Med. 2002;347(4):284-7.

3. Calabrese LH, Albrecht M, Young Y, McCarthy P, Haug M, Jarcho J, et al. Successful cardiac transplantation in an HIV-1-infected patient with advanced disease. N Engl J Med. 2003;348(23):2323-8.

4. Palella FJ Jr, Delaney KM, Moorman AC, Loveless MO, Fuhrer J, Satten GA, et al. Declining morbidity and mortality among patients with advanced human immunodeficiency virus infection. HIV Outpatient Study Investigators. N Engl J Med. 1998;338(13):853-60.

5. Tzakis AG, Cooper MH, Dummer JS, Ragni M, Ward JW, Starzl TE. Transplantation in HIV(+) patients. Transplantation. 1990;49(2): 354-8.

6. Ragni MV, Dodson SF, Hunt SC, Bontempo FA, Fung JJ. Liver transplantation in a hemophilia patient with acquired immunodeficiency syndrome. Blood. 1999;93(3):113-4. 